\title{
CORPORATE SOCIAL RESPONSIBILITY IN FAVOR OF IMPROVING EDUCATION IN SOCIETY (CASE OF PT PERTAMINA REFINERY UNIT VI BALONGAN)
}

\author{
Ilona V. Oisina Situmeang \\ Ilmu Komunikasi, UPI-YAI - Jakarta \\ Alamat surel: ilonaoisina@yahoo.com
}

\begin{abstract}
Corporate Social Responsibility (CSR) is an external activity of a corporate undertaken for the benefit of society. It is expected to facilitate good relationship between the corporate and society. The purpose of this research is to describe Corporate Social Responsibility activity in favor of improving education in society. Research method was using an approach of qualitative descriptive in the case of PT. Pertamina Refinery Unit VI Balongan. Data was collected through conducting in-depth interview, observing, and implementing FGD. The results showed that CSR activity was very beneficial to local society as many of them were be able to continue higher education. Furthermore, local government also found out that CSR has a measurable good impact in local human development index. A long-term goal of CSR is to develop quality human resources to sustain a better life for all.
\end{abstract}

Keywords: Corporate Social Responsibility, Society, Education

\section{PREFACE}

\section{Background of the Study}

Existence of a corporate in a region is a proof that the region has valuable potential in economy, socio-culture, and natural resources as well as other resources, and therefore it is expected to stimulate positive multiplier effect for the surrounding society. It is lamentable if a corporate overexploiting the real potential and widen the gap between corporate and society. An effective communication is needed to eliminate such gap and to support mutual relationship.

Corporate Social Responsibility is one of organizational communication undertaken for the society. A good relationship between stakeholders \& society is expected through this organizational communication. Another point of CSR is to identify the needs of society and common problems usually occur among them. It's been designed to run effectively and in concord with existing programs. CSR is a continually developing concept, giving a guidance of how an organization interact with society and its social spectrum. According to Sarinastiti (2009), the ways in running and communicating about the corporate's attempt in CSR may vary. But most of the time it is more emphasized on the corporate's vision instead of stakeholders' visions or participation in CSR.

Corporate Social Responsibility should be undertaken by considering many aspects of society life so that it will have a long term benefit for all. Communication is the key of success for this CSR and it will certainly help to boost society collective awareness of the corporate's existence. Attempt of communicating CSR effectively will educate the society to be aware of potential benefits; and at the same time building the corporate's brand. An extensive advantage is it will reduce the chance of facing a social volatility.

As a part of modern civilization, a corporate's existence has always been an important issue. CSR, being a part of relationship configuration between business world and the society, is a sub point in this important issue. The conceptual formula of CSR is an ever-changing matter along with dynamic business world itself. At the very first stage in business world - and for quite a long time, CSR was inconceivable since it's pretty much a contra to classic theory by Adam Smith where "the only duty of the corporation is to make profit". The main motivation of every corporation or industry or business is to raise the profit (Djalil, 2003)

According to Widiyanarti (2005), approach of CSR should be done in a 
holistic way, means, approach by the corporate should not be intended merely as a business activity, but also as a movement from charity to a social responsibility emphasized in perpetual society development. The point is helping the society to develop their own sustainable capability in economy, socio-culture, and environment; and therefore the corporate will be able to continually grow with supportive society. In this context, social responsibility is delineated as a long-term investment for the corporate.

Implementation of social responsibility in Indonesia are different from one to another as they depend on policies, visions \& missions, and cultural-matters in each corporates. A synergy between corporate, government, and society is a compulsory in order to succeed the corporate's existence as a cohesion with favorable value. To develop quality human resources, the first step is to be concerned of society education level. CSR as an organizational communication will draw on optimal result if it's maintained consistently for the interests of external public. As well as previously stated points, CSR has a function to minimize negative impacts caused by operational activities and maximize the positive outcome for the society.

As a business entity on the field of energy \& mineral resources, PT Pertamina is well-known as an Indonesian prominent corporate that consistently respect the values of Good Corporate Governance, encompassing responsibility to the environment in every business development it builds. PT Pertamina has an obligation to take social responsibility of society that its existence is assumed to give positive values to the society life, so that the society can acquire benefits of its existence in their surroundings.

Social responsibility implementation of PT Pertamina is a reflection of values and corporate culture integrated with todays and upcoming corporate's business strategy, which provides benefits to PT Pertamina, as well as its shareholders and stakeholders. Given the real condition of society, the implementation of social responsibility is now more prioritized to help the government and society in solving social problems around the area of operations of the corporate. However, the implementation of social responsibility activities are controlled entirely by the corporate through its Public Relations division. Barometer of the success of social responsibility activities undertaken can be viewed from two sides; the corporate and the society. As for the corporate, corporate identity development is one thing to be prioritized. Meanwhile, there should be an improvement in the quality of society life seen from the perceived improvement of the education. It is therefore important for corporate to measure the success of an evaluation of social responsibility activities undertaken by the Public Relations (PR). One important measure of success is if the social responsibility activities manage to give a positive short-term impact such as improvement in the level of society education as well as the long-term goal: to create quality human resources.

The problem of uninspiring education quality in Indonesia is nothing new, we often see a lot of Indonesian people who cannot continue their education because it's unaffordable. Law No. 20/2003 on National Education System obliges every citizen to follow the seven-year-old elementary education. However, there has not been any compensation in implementing the compulsory. Our government had launched nine years of basic education, where every Indonesian child must be at least junior high school graduated. This is a positive thing given the great importance of education for the future. Looking at the phenomenon that occurs in the society showed that the level of education in our country is still very low, Pertamina has the desire to support government regulations with respect to education of the society around the corporate through corporate social responsibility activities in the field of education and support local governments in improving human development index. 


\section{Problem Identification}

From the background of the above problems the author describes the problem: "how is corporate social responsibility undertaken by Pertamina Balongan contributing in improving local public education?"

\section{Research Objectives}

This study aims to answer the question in the case above: "To describe the corporate social responsibility activities undertaken by Pertamina Balongan in improving local public education."

\section{LITERATURE REVIEW}

According to Zelko and Dance in Muhammad (2008), the organizational communication is an interdependent system that includes internal and external communications. Internal communication is a communication within the organization itself as the communication from subordinates to superiors, communication from superiors to subordinates and communication among employees. While external communication is communication by the organization to the external environment in the form of relations with the general public, products communication.

Corporate as a structured system of relationships in which each component is bond together in order to achieve certain goals. The purpose, among others, is as an effort to develop relationships with stakeholders. Public Relations (PR) is required to be a bridge for the corporate and external public. Public Relations has a duty as a corporate representative of which duty is to provide information to the public relating to the corporate. Public Relations according to Jefkins (2003) is a form of communication that is planned, either inside or outside, between an organization with all the audience in order to achieve specific goals based on mutual understanding. Public Relations using the method of management by objectives. In pursuit of a goal, all the yield or rate of progress should be measured clearly, since PR is a real activity. This fact clearly refute the misconceptions which say that PR is an abstract activity.
The Role of Public Relations said by Cutlip, Center and Broom in Ruslan (2008) explains that in essence the main role of public relations is as follows:

a. As a communicator or a liaison between the organization or institution represented by the public. This means that PR act as a communicator in corporate communications activities on the organization, the process takes place in a two traffic reciprocal communication.

b. Fostering relationships, which is fostering positive relationships and mutual benefit with the public. Establish or build relationship is positive and good with the public as a target; the external and internal public. Particularly in the development of creating mutual trust (mutually understanding) and mutual benefit together (mutually Symbiosis) between institutions or organizations with the public.

c. Backing up management role, as a support in the management of the organization or corporate. PR function is attached to the management functions, meaning it is inseperable from management. To achieve this goal in the management functions, according to the theory that the process through the stages of POAC - it stands for Planning, Organizing, Actuating, and Controlling. Then followed by other elements involved in the process of two-way communication to support the activities of other department.

d. Establishing corporate image, meaning that the role of PR trying to create an image for the organization or institution. Creating corporate image is the goal at the end of a PR work program.

Corporate social responsibility concept is understood as a more "humane" in which an organization is viewed as a moral agent. Therefore, with or without the rule of law, a business organization must respect the morality (Nursahid, 2006). 
Corporate Social Responsibility activities undertaken by the organization is a communication undertaken by the corporate with the society. It will help to prevent a possibility of corporate crisis if done consistently and continuously through improved corporate reputation and corporate image in a long-term relationship with the society. In finding out the need, desire, wants, and interests of the society, a survey is required. It is important to create a longterm relationship, hence the corporate starts communicating about expectations related to the relationship. Communicating process in an effort to establish a long term relationship with the society, carried out using the available communication channels. Advantage to be gained by establishing a long term relationship between the organization and the society is to create public trust in the corporate that drives the future investment prospects and establish a prosper life for the surrounding society (Rahman, 2009).

Corporate Social Responsibility contribution is a contribution to a sustainable economic and social development. Sustainable development is working with employees, the public and stakeholders to improve the quality of life in an acceptable way to the business and as well as the development itself as a fundamental value of the CSR. Poverty is a globetrotting social problem, every nation is trying hard to eliminate it, and certainly in the implementation of contemporary CSR, the business and corporate world should recognize their position as part of the society. CSR is a unique activity because the implementation involves society participation around the corporate. Honestly, this is the truth that makes CSR has opportunities for full inclusion of society participation in the achievement of the goal (Untung, 2008).

Corporate Social Responsibility is not intended as a profit-oriented activity as the benefit of CSR is a form of perception and image of the corporate. Realizing the importance of CSR, the corporate is expected to focus on the corporate's relationship with the society. This is a positive phenomenon in the business environment, it has shown an increasing awareness that if the corporate does not aim solely on the profit, but also have to preserve the social and environmental aspects (Harijono, 2007).

Corporate Social Responsibility is a corporate commitment to contribute to the business world in the sustainable economic development by conducting CSR and focus on the balance between attention to the aspects economic, social and environmental. The complexity of social problems become more complicated in the last decade and the implementation of decentralization has put CSR activity as an activity that is expected to provide an alternative breakthrough in active society participation to improve the empowerment of the poor (Putri, 2007).

Indicators of success can be recognized from two sides; companies and communities. From the company side, there must be image improvement in the public eye. Meanwhile, for society, there should be an improvement in quality of life. Therefore, it is important for companies to evaluate in order to measure the success of CSR programs, both quantitatively and qualitatively. One thing to remember, "One important measure of success CSR is if the beneficiaries become independent, not relying on the help of others".

Corporate Social Responsibility models commonly applied in Indonesia by Susiloadi (2008) are:

1. Social responsibility can be carried out directly by the corporate. Corporate running the program as CSR activity directly by organizing their own social activities or deliver donations to the society without any intermediaries. To carry out this task the corporate can assign one of its senior officials like coorporate secretary or public affairs manager or a part of human resource development division assignments or homework.

2. Social responsibility can also be carried out by charities or social organizations or social organizations under the corporate or its group. Corporate established its own foundation or charitable 
organization under the corporate or group that is formed separately from the parent organization of the corporate but still have to be responsible to the board of directors. This model is the adoption of a common practice in developed countries. The corporate providing the initial funding, routine or endowment funds that can be used for the operations of the foundation.

3. Most of the corporates in the running CSR Indonesia through collaboration or partnership with other parties. The corporate maintains CSR through cooperation with government agencies, universities, NGOs, consultants or agencies in managing the funds and implementing social activities.

4. Several corporates joined in a consortium to jointly run the CSR. The corporate has set up a support member or a social institution established for specific social purposes. Trusted consortium by the supporting corporates will proactively seek cooperation from various groups and then develop a program that had been agreed upon.

According to Law no. 20 Year 2003 on National Education System, educational understanding is a conscious and deliberate effort to create an atmosphere of learning and the learning process so that students are actively developing their potential to have the spiritual strength of religious, selfcontrol, personality, intelligence, noble character, and skills needed by themselves, society, and nation.

Related to definition, there are differences between formal education, informal education and non-formal education. In connection with this matter, Coombs (1973) in Fetty (2013) distinguished three types of educational terms as follows:

a. Formal education is a systematic activity, multilevel / hierarchical, starting from elementary school through college or equal; including activity-oriented academic and general, specialized programs, and professional training, which are implemented in continually.

b. Informal education is a process that takes place throughout the ages so that everyone obtain the values, attitudes, skills, and knowledge that comes from everyday life experiences, environmental influences including the influence of family life, relationships with neighbors, work and play environment, market, library, and the mass media.

c. Non-formal education is any organized and systematic activities outside the school system, conducted independently or constitute an important part of a broader activity, which is deliberately done to serve the specific students in achieving learning goals.

\section{RESEARCH METHODOLOGY}

The approach in this study used a qualitative approach with descriptive nature and tend to use inductive analysis approach. Process and meaning (subjective perspective) are more highlighted in the qualitative research. Qualitative research is research that is not concerned with numbers or quantification of the phenomenon. It's socialized with collection and analysis of data in the form of words or direct observation of behavior, so the focus is more on interpretation rather than quantification and highly receptive to subjectivity, thus the valuable subjects are the perspective of the participants and their interpretation of the situation (Cassel \& Symon, 1994). Data was collected by conducting in-depth interview, observation and FGD.

\section{RESULTS AND REVIEW}

As a form of social responsibility towards the local community, many companies are already carrying out activities of corporate social responsibility (CSR). It is because basically the operation of a company is not merely to carry out routine 
activities in the pursuit of profit. But also concerning about the environment so it can grow and prosper together and synergize well, which in turn can create a conducive atmosphere.

Organizational communication is the delivery of messages within an organization that involves all employees in their communication. Organizational communication is understood as delivering and receiving various messages in formal groups and organizations in the informal group. In conducting organizational communication, PT Pertamina Balongan carried out by Government \& Society Relations Division (Hupmas). Organizational communication activities carried out by Pertamina Balongan is fully controlled by the corporate, where Hupmas is appointed to carry out the organization's corporate communications activities. Hupmas run public communications for internal and external to the public.

The goal is an attempt to foster good relations with employees and stakeholders. In running public communication activities with external organizations, Hupmas Pertamina is required to become a bridge between the interests of the corporate with external public desire, which has the task to convey information to the public relating to the corporate. Hupmas is a form of planned communication, either inside or outside ,in order to achieve specific goals based on mutual understanding.

The implementation of CSR program PT Pertamina Balongan is run by public relations, carried out in all areas of public life. One of which is focused in the field of education. In granting assistance in education, health, and social \& religious it is important to maintain the program hand in hand and in line with the work program designed by Indramayu Regent in order to improve the human development index (HDI) in that particular field of education.

Communication process is a highly important subject in an organization which run CSR as a form of social awareness for the surrounding society. Pertamina Balongan has focused its CSR activities in several areas of public life such as: social, economic, environmental, and education.
The field of education is considered as the main program, it is valued as a very beneficial CSR activity for the future of society. It is in line with a statement as expressed by Hupmas Pertamina Balongan staff:

"We conduct the CSR in the field of government to support basic 9-year compulsory education through formal education taken by the people to create quality human resources. In addition to basic 9year compulsory education we also hold a variety of scholarship programs for people who cannot afford to continue their education to a higher level as long as the child is qualified score as the main requirement"

Based on the aforementioned opinion, the corporate's role is not only to encourage healthy economic growth with environmental factors to consider as well (meaning that the development of the corporate or organization is not only seen from financial success in the field of production or services provided to consumers), but corporate must also pay attention to social welfare and improvement of life quality. In this case Pertamina trying to be thoughtful about the social welfare of the society, one of them is a concern for the local society education.

CSR in the field of education is one of the CSR program needs to obtain serious attention from various parties. Education is Indonesian child's rights and needs. The consideration is that Indonesian children are potential and the successor of the struggle of Indonesian nation that has a strategic role in continuing existence of the nation in the future. They are not only the future of the nation, but also the present of the Indonesian nation. To assure every Indonesian child will be able to take responsibility for the future of Indonesia, and that the current generation of Indonesia to support the achievement Indonesian aspirations, then every child without exception must be protected and have their rights fulfilled; such as the right to live, grow and thrive, protected from all form of abuse, as well as the right to voice their opinion and to be listened to. 
In fact we see millions of Indonesian children were in hardship and need immediate rescue and sustainable action. The education sector is a strategic social investments and crucial for the future of a nation, especially in the delivery of excel next generation. But of course not an easy task to prepare an education system that is cheap and quality that can be accessed by all social strata of our society. Delivery of education aid program is intended for underprivileged students with intelligence above-average score. The program has been coordinated and facilitated by the district and local village chief. "In an effort to become actively increase the IPM Indramayu, Pertamina Balongan also previously been carrying out CSR programs in the form of coaching UKS in elementary school (SD) in the area Balongan, training garments for youths in District of Balongan and training of two-wheeled automotive and welding for youth of Indramayu in cooperation with Dinsosnakertrans Indramayu District.

Education is one of the most important areas of life, because education supports human beings to live a better life. This is the main focus Pertamina always act on its commitment to improve the quality of education around the operational area through the corporate's Society Development Program. Society Development Program carried out by Pertamina consists of four sectors of human life, encompasses the social, economic, environmental and education \& training. Disclosed in accordance with one of the Hupmas Pertamina Balongan staff:

"One of the main focus of CSR activities are activities in the field of education and training. Implementation of the policy has always run active from year to year with the launch of various programs include scholarships, educational training, and school infrastructure facilities funding. It is also evident from the CSR program conducted by Pertamina in Jakarta to support public education through direct involvement in the implementation of Pertamina National Science
Olympiad (OSN - Pertamina) 2012. In the fifth year of the OSN - 2012, Pertamina along with the University of Indonesia (UI) as a cooperation partner and fully supported the Directorate General of Higher Education Ministry of Education, carrying the theme "Developing $\boldsymbol{A}$ Generation of Excel Earth Friends". Pertamina OSN - 2012 is an Education Sector CSR program of PT Pertamina as the implementation of the vision in educating the nation's children. We as a branch of Pertamina Jakarta must support CSR activities in the field of education."

Based on observations by the author in Pertamina Balongan, it can be concluded that PT Pertamina Balongan strongly supports the government in creating a quality public education. Underprivileged people are given the opportunity to keep reaching higher education through scholarship programs, it also develops program of educational facilities that can be perceived by the whole society, as well as conducting training for people who are no longer in the age to get a formal education. In carrying out CSR activities in the field of education, Pertamina always actively involves the participation of the society, it aims to explore the society needs for education.

Hupmas of Pertamina's role is to establish relationships that foster good relations and mutually beneficial to the society. One of its activities is to provide assistance to local society in the form of scholarships for underprivileged, both from elementary, junior high, high school and even to the university. It also provides assistance in the form of development such as building rehabilitation for schools in the surrounding area of Pertamina Balongan, as well as the improvement of school facilities and infrastructure. Assistance provided is very beneficial to the local society. As expressed by one of the parents whose children received scholarships from Pertamina said that: 
"Pertamina cares about public education about the less fortunate yet academically excel, like my child. We do not have cost to continue our children's education but Pertamina provides assurance through free tuition and stipends, as long as our children is in the top 3 of their class. This scholarship program is very helpful as we do not have the cost and we hope Pertamina remains concerned about the society education."

The same thing is also expressed by one teacher who perceives the impact of CSR Pertamina's activities in the field of education:

"the quality of education continues to improve, thanks to the help of Pertamina, the indicator can be seen from all sides such as providing IT facillity for students, build libraries and renovating school buildings. Through the construction of schools that support children we can accept students with conducive learning without any fear of a collapsed building that might threat the teachers \& students"

Based on observations, the authors conclude that Hupmas of Pertamina has been conducting CSR in education properly. Including providing scholarships to students with academic achievement and underprivileged parents, giving attention to the development of the school facility, establishing libraries, creating training sessions dedicated for parents to have expertise in specific areas to increase revenue and income for the family. Thus Pertamina not only care about formal education, but also in informal and nonformal education.

In addition to the role of PR that has been carrying out a good job in the CSR above activities, the activities of the CSR actually have a model or pattern in its application. In accordance with the CSR forms, there are four models of pattern which are generally applied in Indonesia, one of them is the partnership with others. The corporate formed a partnership with
Local Government and the competent parties in the planning and implementation of programs, as well as involving the public directly in the planning, implementation and monitoring of the program and conduct programs that directly impact the socioeconomic empowerment in the society around the mine. This can be seen when the corporate provides assistance to one of the schools by establishing the school building and libraries. Pertamina obtained information about the needs of that school from the local government. After obtaining information from local government and the society, Pertamina quickly conduct surveys in person to see the condition of the school and in the process involving the society and school officials directly. In this process the Hupmas staff implement its function as a communicator; to be a liaison of the corporate with the public interests.

For the year 2012 Pertamina allocated generous amount of funds for CSR in the field of education, it is as expressed by Hupmas staff:

"For the 2nd stage of PT Pertamina (Persero) RU VI Balongan, we have submitted greater support than last year. Intended for students of elementary, junior high and high school and college students from three districts in Indramayu, every year it continues to be the year we carried out more and more people who feel the benefits of the CSR activities in the field of education, and hopefully will be the main capital for the society to compete in job competition. Second stage of educational assistance program was intended for college students and disadvantaged students with achievement and above average intelligence. The program has been coordinated and facilitated by the local district and village heads."

Of the opinion above shows that support for education Pertamina conducted so far indicate that Pertamina was always concerned about the education of the people living around the corporate. Through higher education it is expected to create quality 
human resources, so they can be a co-worker one day at Pertamina Balongan. From what the authors has observed, there are already several positions in Pertamina Balongan management line which derived from the local society who excelled \& received scholarship in their graduate study. It indicates that Pertamina wholeheartedly support society to become qualified human resources. The long-term effects can create prosperity for life.

Through the CSR activities in the field of education that has been running for several years, Pertamina become able to help to boost the IPM number of Indramayu in the field of education. Up to now, Indramayu government is only able to accommodate education for the poor as much as 30 percent of them. Besides insufficient allocated-funds for education field, the data showed that impoverished people in Indramayu reached 30 percent of all the citizens. Hence the beneficiaries should utilize them properly for the benefit of their education. The programs provided by Pertamina is a golden opportunity for those who want a higher education.

Corporate Social Responsibility activities in the field of education undertaken not only to support government in succeeding the basic 9-year compulsory education, but also to boost human development index in Indramayu. The activities carried out through activities such as CSR in the field of education are: schools renovation, books donation, computers, training, scholarships and other assistance. CSR activities in this education field is expected to provide benefits to the surrounding society of the importance of education in creating quality human resources.

So many parties who are grateful for the help and support of Pertamina Balongan to the students in Indramayu district, as seen from the FGD that the author did, it shows that local government are grateful for the Pertamina's affection to the local society because it would be hard to support the students without the help of Pertamina due to limited availability of the scholarship program in each year. It's based on the implementation of Permendagri 32 Year
2011 regarding grant guidelines and social assistance sourced from Local Revenue and Expenditure (APBD). Pertamina Balongan sincerely giving affection to the local youth who need support for the education. Otherwise, the students will likely losing the chance of getting higher education. Local government keeps cooperating with other major active corporates in Indramayu in order to continue to contribute positively to the education in Indramayu.

One of the scholarship beneficiaries of Karangampel hawkers son who also received help from Pertamina Balongan CSR gives gratitude to Pertamina:

"I am very grateful to Pertamina and the government that provided a way for me to Pertamina to be able to get this scholarship. My parents hardly suffice the needs of education cost, I'm really hoping that I can get this support until I get to university so that I can make a better living for me \& my family"

It shows that CSR outcome like scholarships is perceived by all the people who excel but do not have the material ability to continue their education, this scholarship program providing opportunities for people who wish to pursue higher education. The scholarship program also helps the government in the success of the basic nine-year compulsory education. However, based on observations by the author conducted, all the people who earned the scholarship program has the obligation to meet a certain required score, if they failed to meet the minimum score then the scholarship can not be extended and will be given to another society. The scholarship beneficiaries has an obligation to study hard to reach the target.

With this scholarship program, Pertamina Balongan have a hope that it will improve the education level index of Indramayu as it has been somehow relatively low. With the expected improvement in local public education, the society will be able to join and work together with the corporate according to each disciplines. It will also provide opportunity for local youth to build a better region. 
In order to build a nation with better quality of intellectual, Pertamina Balongan continue to consistently contribute in the implementation of Corporate Social Responsibility (CSR) in the field of education to contribute in building the nation, for the sake of well-educated generation with advance technology literacy.

The provision of educational assistance should be used properly by the benficiaries through an improvement in the academic achievements of each, so that the administration can be fully beneficial. Many students coming from Indramayu who are now critical to drop out (DO) due to not being able to pay for education. Pertamina is now in cooperation with various parties to save students from several universities to be able to continue to complete their education.

Education Care Program - which is a program of CSR - should be a continuous effort to improve the quality of education of children for the future of the nation. Education is one of the benchmarks used to indicate the well-being of a country. Therefore governments, companies and communities should work together to support formal and informal educational activities for the achievement of the quality development goals.

\section{CLOSING}

\section{Summary}

Based on the purpose of the study and analysis of the above data, it can be concluded that the CSR activities in the field of education is an activity carried out by Pertamina for the success of 9 year compulsory education as a national education program and assist local governments to improve the human development index. Through education funds given, Pertamina itself is coordinating the activities of the CSR to run in accordance with the original purpose and perceived benefits for the local society. Programs undertaken include: providing scholarships for people who excel but cannot afford education, build facilities and infrastructure to support activities such as education, build and renovate school buildings, create libraries, distributing textbooks accounts for a variety of needs for IT developments in schools and so on.

\section{Suggestion}

As expected by the local government and the beneficiaries of CSR activities in the field of education, that this activity is expected to continue on an ongoing basis so that Pertamina Balongan goals can be realized; as the impact of CSR activities in the field of education is not something instant but it will be perceived in years.

\section{BIBLIGIOGRAPHY}

Cassell C; Symon G. 1994. Qualitative Methods in Organizational Research. London: Sage.

Djalil S. 2003. Theoretical and practical context of Corporate Social Responsibility. Journal of Economic Reform. Vol. 4. No. 1:411.

Fetty. 2013. CSR Program of PT Tambang Batubara Bukit Asam In Improving Public Education. Journal of Communication UPI-YAI. Vol. 2.

Harijono T. 2007. CSR should not be seen as charity. Jakarta: Kompas.

Iryani E. 2009. Commitment of company's stakeholders to social and financial performance [thesis]. Semarang : Universitas Diponegoro.

Jefkins F. 2003. Public relations. Fifth Edition. Jakarta: Erlangga.

Nursahid F. 2006. Charitable Practices of SOEs. Analysis of the model of philanthropy of PT. Krakatau Steel, PT. Pertamina, and PT. Telekomunikasi Indonesia. Jurnal Galang Vol 1 No 2: 5-10

Putri SM. 2007. Corporate social responsibility schemes. Jakarta: Kompas.

Rahman R. 2009. Corporate social responsibility: Between theory and reality. Yogyakarta: Med Press.

Ruslan R. 2008. Methods of public relations and communications research. Jakarta: Raja Grafindo Persada. 
Sariastiti N. 2009. Communicating corporate social responsibility. Journal of psychology and social science major's culture of the Universitas Islam Indonesia. Vol 3 No 2 April 2009: 115-126.

Susiloadi P. 2008. Implementation of corporate social responsibility to support sustainable development. Journal of the Faculty of Social Administration Department of State Universitas Sebelas Maret Surakarta. Vol 4 No 2: 123-130.
Untung HB. 2008. Corporate Social Responsibility. Jakarta Sinar Grafika Offset.

Widiyanarti T. 2005. Corporate Social Responsibility : Model comunity development. Journal of Social and Cultural Anthropology. Vol 1 and 2. USU: LPM ANTROP-FISIP. 